\title{
The immune protective efficacy of recombinant outer - membrane protein LolA from Actinobacillus pleuropneumoniae in mice
}

\author{
Yuhang Zhang ${ }^{1 \#}$, Yulong Zhang ${ }^{1 \#, ~ T i n g t i n g ~ Y a n g 1, ~ a n d ~ F u s h e n ~ H u a n g ~}{ }^{1,2 *}$ \\ ${ }^{1}$ College of Veterinary Medicine, Hunan Agricultural University, Changsha, China \\ ${ }^{2}$ Hunan Engineering Technology Research Center of Veterinary Drug, Hunan Agricultural University, \\ Changsha, China
}

ZHANG, Y., Y. ZHANG, T. YANG, F. HUANG: The immune protective efficacy of recombinant outermembrane protein LolA from Actinobacillus pleuropneumoniae in mice. Vet. arhiv 90, 279-287, 2020.

\section{ABSTRACT}

Porcine contagious pleuropneumonia (PCP) is a serious respiratory disease in the pig industry. In the present study, candidate vaccines with broad-spectrum and disease-resistant effects were screened. The App lolA gene was amplified by PCR from the Actinobacillus pleuropneumoniae (App) serotype 1 genome. The bioinformatics analysis results revealed that the App lolA consisted of $633 \mathrm{bp}$, encoding 210 amino acid proteins. In addition, the App LolA shared a high sequence identity among the different App serotypes. In this study, the App lolA was inserted into pET32a (+). The recombinant protein LolA (rLolA) was produced in E. coli BL21 and then determined by sodium dodecyl sulfate polyacrylamide gel electrophoresis (SDS-PAGE) and a Western Blot process. Immune protective efficacy testing of the rLolA was performed in 4-week old BALA/c mice. The serum IgG levels were assayed using an enzyme-linked immune sorbent assay (ELISA) method. The results showed that the serum IgG levels of the mice in the experimental group were significantly higher than those in the Frund incompleted adjuvant (IFA) and saline immunization groups after the third immunization. In particular, significant differences in the high dose group (50 rLolA + IFA) (P<0.01). 50 $\mu \mathrm{g}$ rLolA + IFA, $30 \mu \mathrm{g}$ rLolA + IFA, $30 \mu \mathrm{g}$ rLolA and $10 \mu \mathrm{g}$ rLolA+ IFA treatments had induced $40 \%, 20 \%, 20 \%, 10 \%$ and $10 \%$ survival rates respectively. However, no mice had survived among the adjuvant group and saline groups. The $50 \mu \mathrm{g}$ rLolA + IFA group displayed reductions in lung lesions. Therefore, it was ascertained from these results that the rLolA had induced partial immune protection in the experimental mice against App challenge infections. This study successfully accumulated data valuable for the future exploration of new vaccines for porcine contagious pleuropneumonia.

Key words: Actinobacillus pleuropneumoniae; lolA gene; recombinant LolA; immune protective efficacy

\# These authors contributed equally to this work

\section{Introduction}

Porcine contagious pleuropneumonia (PCP), which is caused by App infection, is an extremely serious respiratory disease which leads to

considerable economic losses in the pig industry. PCP occurs in pigs of all ages, and is characterized by pulmonary fibrosis and hemorrhagic necrosis

\footnotetext{
*Corresponding author:

Prof. Fushen Huang, PhD, College of Veterinary Medicine, Hunan Agricultural University, Furong District, Changsha 410128, China, Phone: +86 7318467 3618; E-mail: 15211071993@163.com
} 
(SASSU et al., 2017). PCP is mainly controlled by the optimization of management and housing conditions, along with antimicrobial therapy and vaccination measures (CHIERS et al., 2010).

The currently available vaccines used for PCP are predominately traditional inactivated bacterins. However, they have been found to supply only partial protection against PCP, with a lack of cross-protection among the main serotypes (SASSU et al., 2017). It has been found that Apx exotoxins are major contributors to the virulence of App (CHIERS et al., 2010). Some previous studies have demonstrated that Apx toxins may potentially induce protective immunity, and have also displayed a wide range of cross-protective effects on a variety of serotypes (SASSU et al., 2017). After immunization with Apx, the clinical manifestations of pleuropneumonia were observed to be improved, and the degrees of lung injuries were reduced (CHIERS et al., 1998; VAN and FREY, 2003; TUMAMAO et al., 2010). However, it has been found that subunit vaccines based on Apx cannot provide complete protection against pleuropneumonia infections (DEL et al., 2014). Along with App toxins, other important vaccine candidates include capsules, lipopolysaccharide (LPS), selective Omps, transferrin binding proteins (Tbp), maltose inducible proteins, peptidoglycanassociated lipo-proteins (PAIA), and outer membrane lipoprotein A (OmlA) (MARTÍNEZMARTÍNEZ et al., 2016; DENEER and POTTER, 1989; FREY et al., 1996; GERLACH et al., 1993). These have also been determined to induce partial immune-protective effects against App infections. In addition, they have also displayed the ability to improve the immune protective efficacy of ApxA exotoxins through fusion (ADKINS et al., 2012; TUMAMAO et al., 2010).

The Omps of gram-negative bacterial pathogens are important functional proteins. They are known to be closely related to many functions, such as the maintenance of the outer membrane structures of bacteria, transport of bacterial cell substrate, and the pathogenesis of bacteria (PATEL et al., 2017). Due to the fact that the Omps are located on the surface of bacterial cells, they are susceptible to attacks by antibodies, which in turn induces immune protection. Furthermore, highly conserved Omps could potentially induce cross-protection effects against pathogen infections (GUO et al., 2017). It has been documented previously that the Omps of Salmonella typhimurium can induce immune protection against infection in mice (ISIBASI et al., 1988). Pasteurella multocida (Pm) Omps have also displayed good immunogenicity (KUMAR et al., 2013). In previous studies, the immunization of mice with rOmp87 resulted in increased antigen specific IgG titres in serum, and provided protection ratings of $66.6 \%$ and $83.3 \%$ following homologous and heterologous challenges, respectively (KUMAR et al., 2013). The accumulation data also revealed that the App Omps had provided protective effects against App infections (LIAO et al., 2009). Meanwhile, the incidence rates and lung lesions were found to be reduced under other serotype infection conditions (HU et al., 2015; CHEN et al., 2012; VAN and FREY, 2003). In the present study, the highly conserved Omp protein LolA was identified by analyzing the App genome. The aim of the present study was to investigate the immune protective efficacy of the recombinant LolA (rLolA) using a mouse model.

\section{Materials and methods}

Bacterial strains and growth conditions. In present study, App Serotype I strains were inoculated onto a Tryptic Soy Broth (TSB, Beijing Luqiao Technology Co., Ltd. China) solid medium, containing 5\% Mycoplasma free Neonatal Cattle Serum (Beijing Luqiao Technology Co., Ltd. China) and $10 \mu \mathrm{g} / \mathrm{mL}$ of NAD (Beijing Dingguo Biotechnology Co., Ltd. China), and maintained at $37{ }^{\circ} \mathrm{C}$ overnight. A single colony was selected and inoculated into the TSB liquid medium for six hours at $37{ }^{\circ} \mathrm{C}$ on a shaker. Then, the bacteria were collected by centrifugation at $5,000 \mathrm{~g}$.

Cloning and bioinformatics analysis of App lolA gene. The primer pairs (forward primer F1: ATTGTCCCAAGAGTATAA and reverse primer R1: CTAATGTGTTTACTGATT) were designed on the basis of some sequences of the App lolA gene publicly available in the GenBank. In this study, the App lolA gene was amplified from the App serotype I genome via PCR. The PCR reaction 
conditions were as follows: Initial denaturation at $95{ }^{\circ} \mathrm{C}$ for three minutes; followed by 30 cycles of denaturation at $94{ }^{\circ} \mathrm{C}$ for 50 seconds, annealing at 55 ${ }^{\circ} \mathrm{C}$ for 30 seconds, extension at $72{ }^{\circ} \mathrm{C}$ for 45 seconds and a final extension at $72{ }^{\circ} \mathrm{C}$ for ten minutes. The PCR product was detected using an agarose gel electrophoresis method, and then sequenced by Shanghai Biological Engineering Co. Ltd. (China). An open reading frame (ORF) analysis was performed using ORF finder software. The signal peptide sequence of the protein was analyzed using a SinalP 4.1 server. The transmembrane region of the protein was analyzed using a TMHMM server, version 2.0. The results of the amino acid sequence alignment analysis of LolA in this study, along with others downloaded from GenBank, were analyzed using DNAMAN software.

B-cell epitopes prediction of App LolA. B-cell epitope predictions of the App LolA were obtained using online software, namely, the process was first completed using ABCpred (http://www. imtech.res.i-n/raghava/abcpred), and confirmed by COBEPro (http://scratch.proteomics.ics.uci.edu), BepiPred-2.0 (http://www.cbs.dtu.dk/services/ BepiPred/), and Vaxipred (http://www.Imtech.r-es. in/raghava/bcepred/). Then, Vaxipred was used for analysis of the hydrophilicity, plasticity, and surface accessibility of the App LolA.

Construction of the recombinant plasmids. The App lolA coding sequence (not including the signal peptide sequence) was amplified by PCR. The primer pairs were: F2: 5' CGCGGATCCGCGATAGTATCGTCCAA CCGCTTAG 3' (BamHl), and R2: 5'CCCAAGCTTGGGAAACCAGACCGCTTCATTC GTC 3' (Hind III). The PCR conditions were as follows: Initial denaturation at $95{ }^{\circ} \mathrm{C}$ for three minutes; followed by 30 cycles of denaturation at $94^{\circ} \mathrm{C}$ for 50 seconds, annealing at $55^{\circ} \mathrm{C}$ for 30 seconds, extension at $72^{\circ}$ $\mathrm{C}$ for 45 seconds and a final extension at $72^{\circ} \mathrm{C}$ for ten minutes. Following the completion of the purification process, the PCR product and pET 32(a) vector were digested with BamHI and Hind III (Takara Co., Ltd. China), and then ligated with T4 DNA ligase (Takara Co., Ltd. China). At that point in this study the recombinant plasmid pET32LolA was transformed into competent cells of $E$. coli BL21 (DE23) using a heat shock method. The recombinant clones were selected on Luria Broth (LB) agar containing ampicillin $(100 \mu \mathrm{g} / \mathrm{mL})$. The recombinant plasmid pET32-LolA was verified by the restriction enzyme digestion and nucleotide sequence analysis methods (HU et al., 2017).

Expression and purification of recombinant proteins. The E. coli BL21 cells carrying pET32lolA were grown in Luria Broth (LB), supplemented with $100 \mu \mathrm{g}$ ampicillin/mL. Then, the recombinant clones at the mid-log phase were induced with a final concentration of $1 \mathrm{mM}$ of isopropyl- $\beta$-Dgalactopyranoside (Sigma, China) for a three- hour period prior to harvesting the cells. The selected cells were washed twice with phosphate-buffered saline (PBS) $\mathrm{pH} 7.2$ solution and resuspended in PBS at a ratio of 1:20 of the original culture volume. The cells were disrupted using a CP70T Ultrasonic Processor (Cole-Parmer, USA) for 6 to 10 seconds at $60 \%$ amplitude. The cell lysates were harvested and washed twice with PBS. The recombinant proteins were purified using $8 \mathrm{~mol} / \mathrm{L}$ urea and maintained at $-20{ }^{\circ} \mathrm{C}$ for future use. The purified proteins were determined using SDSPAGE and Western Blot methods (HU et al., 2017).

Western Blot analysis results. In the present study, the recombinant proteins were first run on a $10 \%$ SDS-polyacrylamide gel and then transferred to nitrocellulose membranes using a semi-dry blotting system (Beijing Liuyi Co., Ltd., China). Each lane was separated by cutting the nitrocellulose membrane. The primary antibodies were murine normal serum and App-infected murine serum, respectively. Western Blot analysis was carried out using the respective primary antibodies at a dilution rate of 1:200. In addition, goat anti-mouse IgG conjugated to horseradish peroxidase (HRP) (Sigma, China) was used as the secondary antibody at a dilution rate of 1:10,000. DAB was used for color detection and a pre-stained protein Marker 10-250KD (Beijing Quantum Biotechnology Co., Ltd. China) was used as the size marker (HU et al., 2017).

Immunization and challenge experiments. In the current study's experiments, 60 four-week old female BALB/c mice, weighing between 16 and 18 $\mathrm{g}$ were randomly divided into six groups of 10 mice 
each. The mice in four of the experimental groups were respectively subcutaneously (SC) inoculated with a low-dosage adjuvant (Freund's incomplete adjuvant $+10 \mu \mathrm{g}$ rLolA); medium-dosage adjuvant (Freund's incomplete adjuvant+ $30 \mu \mathrm{g}$ rLolA); highdosage adjuvant (Freund's incomplete adjuvant +50 $\mu \mathrm{g}$ rLolA); and medium-dosage (30 $\mu \mathrm{g}$ rLolA) at weeks 0,2 , and 4 . The Freund's incomplete adjuvant was purchased from Beijing Solarsoft Technology Co., Ltd. (China). The mice in the remaining two parallel control groups were subcutaneously (SC) injected with normal saline and Freund's incomplete adjuvant, respectively. Then, the mice were intraperitoneally challenged with $10 \times \mathrm{LD}_{50} \mathrm{App}$ at two weeks after the third immunization process. The survival rates were calculated post-infection with the survival rate equaling the number of survivors/ number of animals used in the experiments, times the percentage of survivors. The mice were tail bled on the first day and again at one day prior to both booster vaccinations and challenges (weeks 0 , 2,4 , and 6 , respectively). The sera were stored at $-20^{\circ} \mathrm{C}$ for further use. All the animal experiments in this study were performed with the approval of the Ethics Committee on Animal Experimentation of Hunan Agricultural University (HU et al., 2017).

Determination of the antibody responses to the vaccine formulations. The IgG titers of the specific antibody responses in the murine sera were determined using an enzyme-linked immunosorbent (ELISA) assay method. In summary, 96-well polystyrene microtiter plates were coated with purified rLolA (10 $\mu \mathrm{g} /$ well), and then incubated overnight at $4^{\circ} \mathrm{C}$. After three washes with PBST, the plates were blocked by incubation with a blocking solution (1\% BSA in PBS) for two hours at $37{ }^{\circ} \mathrm{C}$. After the plate was washed again, $100 \mu \mathrm{L}$ of the diluted murine serum $(1: 4000)$ was added to each well followed by an incubation period of two hours at $37^{\circ} \mathrm{C}$. Then, rabbit anti-mouse IgG conjugated to horseradish peroxidase (HRP) (Sigma, China) was used as a secondary antibody $(100 \mu \mathrm{L} /$ well $)$ at a dilution rate of 1:4000, and incubated for two hours at $37{ }^{\circ} \mathrm{C}$. At this point in the experiment, TMB (3.3.5.5-Tetramethylbenzidine, Beijing Dingguo Biotechnology Co., Ltd. China) was adopted as the colorimetric reagent. The reactions was terminated by adding $100 \mu \mathrm{L}$ of $2 \mathrm{~mol} / \mathrm{L} \mathrm{H}_{2} \mathrm{SO}_{4}$. The plates were read at $450 \mathrm{~nm}$ on a microtiter plate reader, in order to determine optical density (OD). All the assays were performed in triplicate.

Statistical analysis results. Statistical analyses were performed in the present study using SPSS software. The data were expressed as the mean \pm $\mathrm{SD}$, and a $P$ value of less than 0.05 was considered to be statistically significant.

\section{Results}

Cloning and analysis of the App lolA gene. The PCR product of the App lolA gene was detected and appeared at approximately $750 \mathrm{bp}$ on agarose gel electrophoresis, as detailed in Fig. 1.

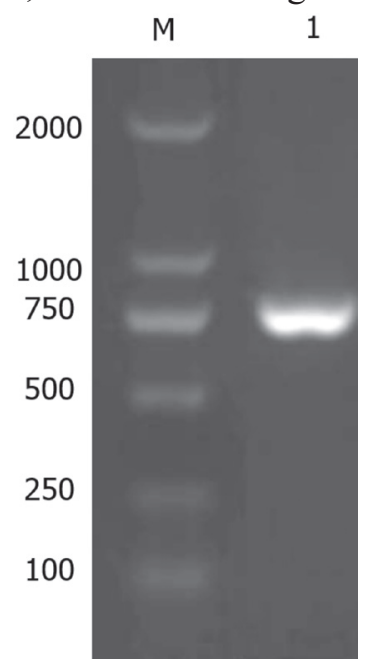

Fig. 1. Electrophoretic map of Lola PCR product. M DNA Marker; 1 - Lola PCR product

After the sequence was sequenced, it was found that the App lolA gene (Bankit 2090091) contained a coding nucleotide sequence of $633 \mathrm{bp}$ in length, which encoded an outer membrane protein of 210 amino acids. The theoretical molecular weight and pI of the App LolA were 2,3458 dalton and 9.70, respectively. The results of this study's multiple sequence alignment analysis indicated that the amino acid sequence displayed higher than 99\% identity with the different App serotypes in GenBank (App ser 1 str. 4074 AWG94892.1; App ser 2 str. 4226 EFL79115.1; App ser 3 str. JL03 WP_012262832.1; App ser 4 str. M62 EFM90298.1; A pp ser 5b str. L20 A3MZJ2.1; App ser 6 str. Femo EFL81040.1; App ser 7 B3GX52.1; App ser 8 CUU51798.1; App 
ser 9 WP_005609863.1; App ser 10 str. D13039 EFM96841.1; App ser 11 str. 56153 EFM98933.1; App ser 12 str. 1096 EFN01056.1; and App ser 13 str. N273 EFN03227.1). These findings suggest that the App LolA protein was highly conserved among the App strains, with the potential to induce a cross-protective effect against App. In addition, using in-silico analysis methods (the web server ABCpred, COBEPro and BepiPred-2.0), along with hydrophilicity, accessibility and plasticity analysis processes, it was also found that three linear B cell epitopes could potentially be identified in the 59$65,170-175$, and 198-202 amino acid regions of the App LolA (Table 1).

Table 1. The putative B cell epitopes of App LolA protein

\begin{tabular}{|c|c|c|}
\hline Number & Position & Amino acid sequences \\
\hline 1 & $59-65$ & SGKGKFQ \\
\hline 2 & $170-175$ & RDGQSN \\
\hline 3 & $198-202$ & KGTEL \\
\hline
\end{tabular}

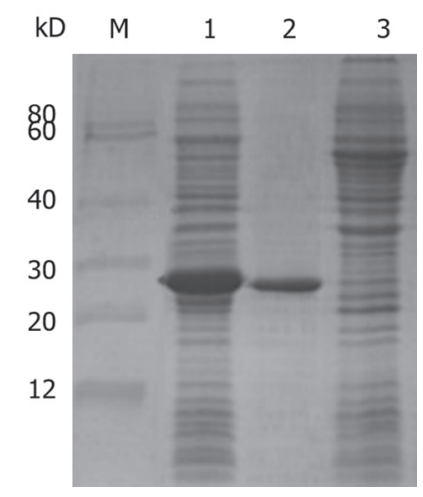

Fig. 2. SDS-PAGE analysis of rLOLA. M - protein Marker; 1 - Recombinant bacteria with IPTG induction; 2 - Purfied rLOLA; 3 - Recombinant bacteria without IPTG induction

SDS-PAGE and Western Blot determinations of the rLolA. In the present study, the recombinant protein from the $E$. coli BL21 cells carrying pET32LolA, which contained the coding sequences of the App lolaA gene, was detected in the cell lysates and purified products. As detailed in Fig. 2, these appeared at approximately $28 \mathrm{kDa}$ ( a protein with some tag sequences in pET-32(a)) on the SDS-PAGE gel. This suggested that the rLolA was successfully produced by the E. coli BL21 harboring the pET32-
LolA with the lolA gene inserted. In regard to the results of this study's Western Blot analysis of the App infected murine sera, it was found that the serum of the App infected mice reacted with the purified recombinant protein, which indicated that the rLolA displayed a good immunogenicity effect (Fig. 3).

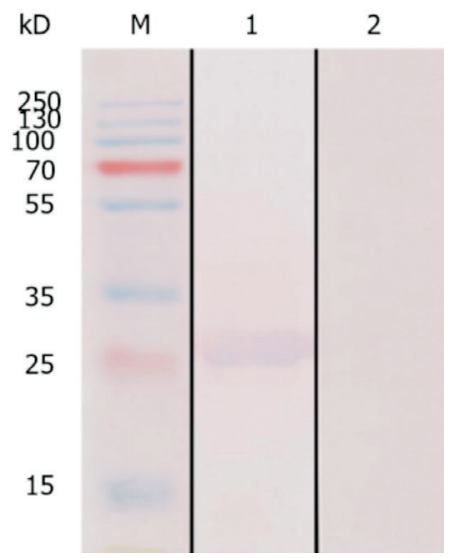

Fig.3. Western blot detection of rLOLA. M - Protein standard Maker; 1 - Determination of positive sera of infected- mice by App; 2 - Determination of negative sera of normal mice

Immune responses against $r$ LolA proteins and their protective efficacy. In this study, the BALB/c mice were inoculated subcutaneously three times. The sera were collected at day 0 , and again prior to both the inoculations and the challenges (days 14 and 28 , respectively), and utilized for measurements of the IgG titers.

As shown in Fig. 4, the serum IgG levels in the mice which had been vaccinated with rLolA + adjuvant were significant. In particular, in the high dosage group $(50 \mu \mathrm{g}+$ adjuvant $)(\mathrm{P}<0.01)$, the levels had noticeably increased after the second immunization. Then, on the fourth day of the App infection, the protective efficacy of the rLolA proteins was observed. The experimental results showed that the vaccine formulations composed of Freund's incomplete adjuvant $+50 \mu \mathrm{g}$ rLolA, Freund's incomplete adjuvant $+30 \mu \mathrm{g}$ rLolA, Freund's incomplete adjuvant $+10 \mu \mathrm{g}$ rLolA, and the $30 \mu \mathrm{g}$ rLolA had conferred $40 \%, 20 \%, 10 \%$, and $20 \%$ protection rates in the mice, respectively. The differences in the protection rates between the immunized group and the control group (adjuvant group and saline group) were found to be 
significant. It was observed that all the control mice had died. The lungs of the mice immunized with Freund's incomplete adjuvant $+50 \mu \mathrm{g}$ rLolA showed reductions in lung lesions when compared with the mice of the other immunized groups. The clinical condition of the surviving mice gradually returned to normal and they began to eat again. These results indicated that the subcutaneous injections of rLolA had induced immune responses and partial immune protection in the mice examined in this study's experiments.

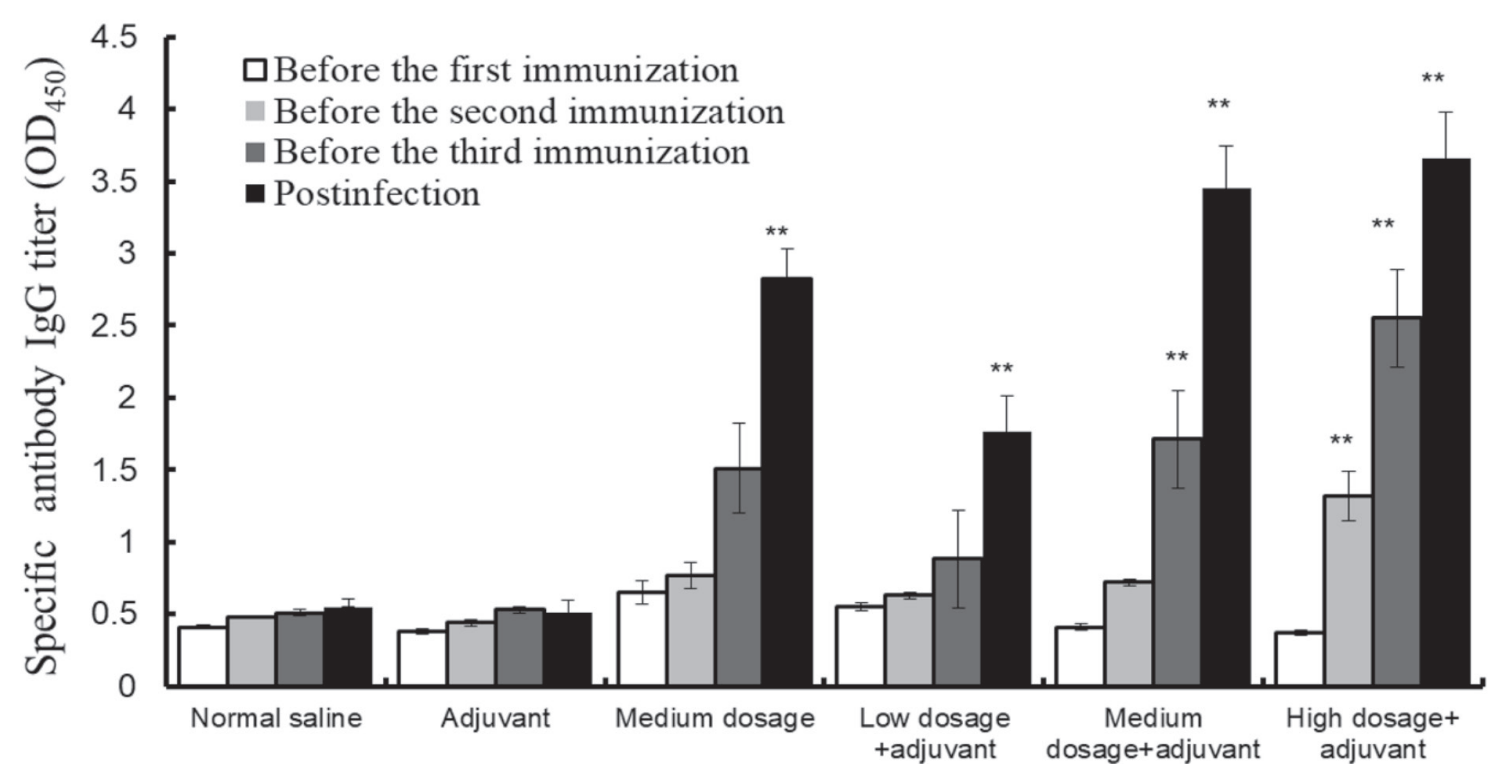

Fig. 4. Level of antibody IgG against rLOLA before/after immunization and infection

Note: Medium dosage: $30 \mu \mathrm{g}$ rLOLA; Low dosage +adjuvant: $10 \mu \mathrm{g}$ rLOLA+ IFA; Medium dosage +adjuvant: $30 \mu \mathrm{g}$ rLOLA + IFA; High dosage + adjuvant: $50 \mu \mathrm{g}$ rLOLA +IFA; ** indicted very significant difference (experimental groups $v s$ control groups, $\mathrm{P}<0.01)$

\section{Discussion}

In this study, the results of the bioinformatics analysis showed that the App LolA was a transmembrane binding protein with 211 amino acids, and had high identity among the different serotypes of App. It also showed that this protein contained three linear B cell epitopes. The West Blot results indicated that the rLolA had reacted with the positive sera of App-infected mice. These findings suggested that App LolA had an immunogenicity effect and could potentially induce cross-protection against different App serotypes.

Bacterial LolA is a peripheral protein which plays an important role in the sorting and outer membrane localization of lipoproteins in bacteria (ZÜCKERT, 2014; GRABOWICZ and SILHAVY, 2017). Lipoproteins are anchored to the periplasmic sides of either the inner or outer membranes. Following their expressions in cells, they must be sorted and located into the inner or outer membranes by other protein complexes. It has been reported that five Lol proteins are involved in the sorting and outer membrane localization of lipoproteins (NARITA and TOKUDA, 2010). LolCDE is composed of one copy each of the membrane subunits LolC and LolE, and two copies of the nucleotide-binding subunit LolD (YASUDA et al., 2009). It is an ATP binding cassette (ABC) transporter which releases outer membranedirected lipoproteins from the inner membrane in an ATP-dependent manner. This subsequently leads to the formation of a water-soluble complex between the lipoprotein and LolA (REMANS et al., 2010). The LolA-lipoprotein complex crosses the periplasm and then interacts with the outer membrane receptor LolB. This is known to be essential for the anchoring of the lipoproteins to 
the outer membranes (COLLIN et al., 2011). Previous research results regarding uropathogenic Escherichia coli (UPEC) revealed that the lolA were poorly expressed in vitro (in human urine or LB medium), yet highly expressed in vivo. It was observed that LolA could potentially react with UPEC-infected mouse sera, demonstrating good immunogenicity. Therefore, they could be useful as potential vaccine targets (VIGIL et al., 2011). In this study, it was found that the levels of serum IgG antibodies increased significantly in the mice after the third immunization in the recombinant protein rLolA and rLolA+ adjuvant groups. It was found that the rLolA and rLolA+ adjuvant had the ability to induce survival rates between $10 \%$ and $40 \%$, respectively, in the examined mice.

Some previous research studies regarding App Omps as vaccine candidates have been reported. The results of Immunoproteomic analyses of Omps confirmed that the App Omp displayed good immunogenicity effects (LIAO et al., 2009). IN ADDITION, Vaccination procedures using Apx/rApx pluse Omps were determined to have the potential to both increase protection and significantly reduce lung lesions in mice and pigs (WANG et al., 2009; DEL et al., 2014; WANG et al., 2006). Meanwhile, this type of formula could also induce a cross reaction against different App serotypes (DEL et al., 2014). In this study, it was confirmed that the mice immunized with $50 \mu \mathrm{g}$ rLolA + adjuvant showed a reduction in lung lesions when compared with the mice in the other immunized groups.

As mentioned in the above results, this study accumulated basic data for further exploration of new vaccines against porcine infectious pleuropneumonia.

\section{Conflicts of interest}

The authors declare that this research project was performed without any personal, professional, or financial conflicts of interest.

\section{Acknowledgements}

This research was supported by the Key Project of Department of Education in Hunan Province, P.R.C. (Grant number 16A101).

\section{References}

ADKINS, I., J. HOLUBOVA, M. KOSOVA, L. SADILKOVA (2012): Bacteria and their toxins tamed for immunotherapy. Curr. Pharm. Biotechnol. 13, 1446-1473.

DOI: $10.2174 / 138920112800784835$

CHEN, X., Z. XU, L. LI, H. CHEN, R. ZHOU (2012): Identification of conserved surface proteins as novel antigenic vaccine candidates of Actinobacillus pleuropneumoniae. J. Microbiol. 50, 978-986.

DOI: $10.1007 / \mathrm{s} 12275-012-2214-2$

CHIERS, K., I. VAN OVERBEKE, P. DE LAENDER, R. DUCATELLE, S. CAREL, F. HAESEBROUCK (1998): Effects of endobronchial challenge with Actinobacillus pleuropneumoniae serotype 9 of pigs vaccinated with inactivated vaccines containing the Apx toxins. Vet. Q. 20, 65-69.

DOI: $10.1080 / 01652176.1998 .9694841$

CHIERS K, T. D. WAELE, F. PASMANS, R. DUCATELLE, F. HAESEBROUCK (2010): Virulence factors of Actinobacillus pleuropneumoniae involved in colonization, persistence and induction of lesions in its porcine host. Vet. Res. 41, 65-81.

DOI: $10.1051 /$ vetres/2010037

COllin, S., I. GUILVOUT, N. N. NICKERSON, A. P. PUGSLEY (2011): Sorting of an integral outer membrane protein via the lipoprotein-specific Lol pathway and a dedicated lipoprotein pilotin. Mol. Microbiol. 80, 655-665. DOI: 10.1111/j.1365-2958.2011.07596.x

DEL, P. S. R., A. MICHIELS, M. MARTENS, F. HAESEBROUCK, D. MAES (2014): Efficacy of vaccination against Actinobacillus pleuropneumoniae in two Belgian farrow-to-finish pig herds with a history of chronic pleurisy. Vet. Rec. 174, 333-334.

DOI: $10.1136 /$ vr.101961

DENEER, H. G., A. A. POTTER (1989): Effect of iron restriction on the outer membrane proteins of Actinobacillus (Haemophilus) pleuropneumoniae. Infect. Immun. 57, 798-804.

FREY, J., P. KUHNERT, L. VILLIGER, J. NICOLET (1996): Cloning and characterization of an Actinobacillus pleuropneumoniae outer membrane protein belonging to the family of PAL lipoproteins. Res. Microbiol. 147, 351361.

DOI: $10.1016 / 0923-2508(96) 84710-3$

GERLACH, G. F., C. ANDERSON, S. KLASHINSKY, A. ROSSI-CAMPOS, A. A. POTTER, P. J. WILLSON (1993): Molecular characterization of a protective outer membrane lipoprotein (OmlA) from Actinobacillus pleuropneumoniae serotype 1. Infect. Immun. 61, 565.

GRABOWICZ, M., T. J. SILHAVY (2017): Redefining the essential trafficking pathway for outer membrane lipoproteins. Proc. Natl. Acad. Sci. USA. 114, 4769-4774. DOI: $10.1073 /$ pnas. 1702248114 
GUO, Y., L. HE, N. SONG, P. LI, S. SUN, G. ZHAO, W. TAI, S. JIANG, L. DU, Y. ZHOU (2017): Highly conserved M2e and hemagglutinin epitope-based recombinant proteins induce protection against influenza virus infection. Microbes Infect. 19, 641-647.

DOI: 10.1016/j.micinf.2017.08.010

HU, X., H. YAN, K. LIU, J. HU, C. QI, J. YANG, Y. LIU, J. ZHAO, J. LIU (2015): Identification and characterization of a novel stress-responsive outer membrane protein Lip40 from Actinobacillus pleuropneumoniae. BMC Biotechnol. $15,1-11$.

DOI: $10.1186 / \mathrm{s} 12896-015-0199-8$

HU, P. P., T. T. YANG, F. S. HUANG, Z. S. TANG, Y. H. ZHANG (2017): Immune protection research against challenge infection in mice (Mus musculus) Induced byAPPrOmpP2 of Porcine (Sus scrofa). J. Agricult. Biotechnol. 25, 299-306.

DOI: 10.3969/j.issn.1674-7968.2017.02.015

ISIBASI, A., V. ORTIZ, M. VARGAS, J. PANIAGUA, C. GONZÁlEZ, J. MORENO, J. KUMATE (1988): Protection against Salmonella typhi infection in mice after immunization with outer membrane proteins isolated from Salmonella typhi 9,12,d, Vi. Infect. Immun. 56, 2953-2959.

KUMAR, A., R. YOGISHARADHYA, M. A. RAMAKRISHNAN, K. N. VISWAS, S. B. SHIVACHANDRA (2013): Structural analysis and cross-protective efficacy of recombinant $87 \hat{\mathrm{A}} \mathrm{kDa}$ outer membrane protein (Omp87) of Pasteurella multocida serogroup B:2. Microb. Pathog. 65, 48-56.

DOI: 10.1016/j.micpath.2013.09.007

LIAO, Y. H., J. H. DENG, A. D. ZHANG, M. ZHOU, Y. HU, H. CHEN, M. JIN (2009): Immunoproteomic analysis of outer membrane proteins and extracellular proteins of Actinobacillus pleuropneumoniae JL03 serotype 3. BMC Microbiology. 9, 172-172.

DOI: $10.1186 / 1471-2180-9-172$

MARTÍNEZ-MARTÍNEZ, S., R. FRANDOLOSO, E. F. RODRÍGUEZ-FERRI, M. J. GARCÍA-IGLESIAS, C. PÉREZ-MARTÍNEZ, Á. ÁlVAREZ-ESTRADA, C. B. GUTIÉRREZ-MARTÍN (2016): A vaccine based on a mutant transferrin binding protein $\mathrm{B}$ of Haemophilus parasuis induces a strong T-helper 2 response and bacterial clearance after experimental infection. Vet. Immuno.1 Immunopathol. 179, 18-25.

DOI: 10.1016/j.vetimm.2016.07.011

NARITA, S., H. TOKUDA (2010): Sorting of bacterial lipoproteins to the outer membrane by the Lol system. Methods Mol. Biol. 619, 117-129.

DOI: 10.1007/978-1-60327-412-8_7

PATEL, D. S., Y. QI, W. IM (2017): Modeling and simulation of bacterial outer membranes and interactions with membrane proteins. Curr. Opin. Struct. Biol. 43, 131-140.

DOI: $10.1016 /$ j.sbi.2017.01.003
REMANS, K., K. PAUWELS, U. P. VAN, L. BUTS, P. CORNELIS, J. TOMMASSEN, S. N. SAVVIDES, K. DECANNIERE, P. VAN GELDER (2010): Hydrophobic surface patches on LolA of Pseudomonas aeruginosa are essential for lipoprotein binding. J. Mol. Biol. 401, 921930.

DOI: 10.1016/j.jmb.2010.06.067

SASSU, E. L., J. T. BOSSÉ, T. J. TOBIAS, M. GOTTSCHALK, P. R. LANGFORD, I. HENNIG-PAUKA (2017): Update on Actinobacillus pleuropneumoniae-knowledge, gaps and challenges. Transbound. Emerg. Dis. (Suppl) 1, 72-90.

DOI: $10.1111 /$ tbed.12739

TUMAMAO, J. Q., R. E. BOWLES, D. B. H. VAN, H. L. KLAASEN, B. W. FENWICK, P. J. BLACKALL (2010): An evaluation of the role of antibodies to Actinobacillus pleuropneumoniae serovar 1 and 15 in the protection provided by sub-unit and live streptomycin-dependent pleuropneumonia vaccines. Aust. Vet. J. 82, 773-780.

DOI: 10.1111/j.1751-0813.2004.tb13248.x

VAN, D. B. H., J. FREY (2003): Interference of outer membrane protein PalA with protective immunity against Actinobacillus pleuropneumoniae infections in vaccinated pigs. Vaccine. 21, 3601-3607.

DOI: $10.1016 / \mathrm{s} 0264-410 \times(03) 00410-9$

VIGIL, P. D., C. J. ALTERI, H. L. MOBLEY (2011): Identification of in vivo-induced antigens including an RTX family exoprotein required for uropathogenic Escherichia coli virulence. Infect. Immun. 79, 2335-44.

DOI: 10.1128/IAI.00110-11.

WANG, C. L., W. YONG, M. L. SHAO, W. SI, H. LIU, Y. CHANG (2009): Positive role for rApxIVN in the immune protection of pigs against infection by Actinobacillus pleuropneumoniae. Vaccine 27, 5816-5821.

DOI: 10.1016/j.vaccine.2009.07.065

WANG, Y., S. G. LIU, C. L. WANG, M. L. SHAO, Q. GONG, J. D. LIU, L. CHI, K. ZHAO, S. P. GUO, G. X. LI (2006): Evaluation of protective efficacy of recombinant subunit vaccine against PCP and its immunologic mechanisms. Chinese Veterinary Science. 36, 955-960. (In Chinese)

YASUDA, M., IGUCHI-YOKOYAMA A, MATSUYAMA S, TOKUDA H, S NARITA (2009): Membrane topology and functional importance of the periplasmic region of $\mathrm{ABC}$ transporter LolCDE. Biosci. Biotechnol. Biochem. 73, 2310-2316.

DOI: $10.1271 / \mathrm{bbb} .90451$

ZÜCKERT, W. R. (2014): Secretion of bacterial lipoproteins: through the cytoplasmic membrane, the periplasm and beyond. Biochim. Biophys. Acta. 1843, 1509-16.

DOI: : 10.1016/j.bbamcr.2014.04.022. 


\section{ZHANG, Y., Y. ZHANG, T. YANG, F. HUANG: Imunozaštitno djelovanje rekombinantne vanjske membrane proteina LolA od bakterije Actinobacillus pleuropneumoniae u miševa. Vet. arhiv 90, 279-287, 2020.}

\section{SAŽETAK}

Zarazna pleuropneumonija svinja (PCP) teška je respiratorna bolest u svinjogojskoj industriji. U ovom su istraživanju analizirana kandidatna cjepiva širokog spektra i njihova učinkovitost u otpornosti na tu bolest. Gen App lolA umnožen je PCR-om od genoma serotipa 1 Actinobacillus pleuropneumoniae (App). Rezultati bioinformatičke analize pokazali su da se App lolA sastoji od 633 bp, kodirajući 210 aminokiselinskih proteina. Također, App LolA dijeli visoki stupanj prepoznatljivosti sekvenci među različitim serotipovima App. U ovom je istraživanju App lolA umetnut u pET32a $(+)$ plazmid. Rekombinantni protein LolA rLolA je proizveden u E. coli BL21 i zatim određen poliakrilamidnom (SDS-PAGE) gel-elektroforezom i western blot metodom. Testiranje imunozaštitnog djelovanja rLolA provedeno je u miševa BALA/c starih četiri tjedna. Serumske razine IgG analizirane su primjenom metode ELISA. Rezultati su pokazali znakovito više serumske razine IgG-a u miševa u eksperimentalnoj skupini od onih u skupini s adjuvansom (IFA) i skupini sa soli nakon treće imunizacije. Navedeno posebno vrijedi za znakovite razlike u skupini sa visokim dozama (50 rLolA + IFA) $(\mathrm{P}<0,01)$.Stope preživljavanja po skupinama iznosile su $40 \%(50 \mu \mathrm{g}$ rLolA + IFA), $20 \%$ (30 $\mu \mathrm{g}$ rLolA + IFA), $20 \%$ (30 $\mu \mathrm{g}$ rLolA) and $10 \%$ (10 $\mu \mathrm{g}$ rLolA+ IFA). U skupinama u kojima je imunizacija provedena s adjuvansom i solju nije bilo preživjelih miševa. Skupina $50 \mu \mathrm{g}$ rLolA + IFA pokazala je smanjenje plućnih lezija. Rezultati ovoga istraživanja upućuju da je rLolA izazvao djelomičnu imunosnu zaštitu od infekcija izazvanih App-om u pokusnih miševa i kao takvi daju doprinos za buduća istraživanja cjepiva protiv zarazne pleuropneumonije svinja.

Ključne riječi: Actinobacillus pleuropneumoniae; gen lolA; rekombinantni LolA; učinkovitost imunozaštite 
